\title{
Reclassification of Lactobacillus casei subsp. casei ATCC 393 and Lactobacillus rhamnosus ATCC 15820 as Lactobacillus zeae nom. rev., Designation of ATCC 334 as the Neotype of $L$. casei subsp. casei, and Rejection of the Name Lactobacillus paracasei
}

\author{
L. M. T. DICKS, ${ }^{1 *}$ E. M. Du PLESSIS, ${ }^{1}$ F. DELLAGLIO,${ }^{2} \dagger$ AND E. LAUER ${ }^{3}$ \\ Department of Microbiology, University of Stellenbosch, Stellenbosch 7600, South Africa ; Dipartimento \\ di Scienze e Technologie Agro-Alimentari, Ambientali e Microbiologiche, Universita \\ degli Studi del Molise, Campobasso 86100, Italy ${ }^{2}$; and \\ Zyma GmbH, Berlin 12057, Germany ${ }^{3}$
}

\begin{abstract}
The type strain of Lactobacillus casei subsp. casei (ATCC 393) exhibits low levels of DNA homology with other strains of $L$. casei subsp. casei (8 to 46\%) and strains of Lactobacillus paracasei ( 30 to $50 \%$ ), but exhibits a level of DNA similarity of $80 \%$ with Lactobacillus rhamnosus ATCC 15820, the original type strain of "Lactobacterium zeae" Kuznetsov 1959. Strains ATCC 393 ${ }^{\mathrm{T}}$ ( $\mathrm{T}=$ type strain) and $\mathrm{ATCC} 15820^{\mathrm{T}}$ are members of one protein profile cluster that is separate from the other Lactobacillus spp. The randomly amplified polymorphic DNA PCR profile of strain ATCC $393^{\mathrm{T}}$ is also different from the profiles obtained for the other species. $L$. casei ATCC $3^{T} 4^{T}$ is genetically closely related to $L$. case $i$ subsp. case $i$ strains $(71$ to $97 \%$ ) and $L$. paracase $i$ strains $(71$ to 91\%), is a member of the same protein profile cluster as these organisms, and shares several DNA amplicons

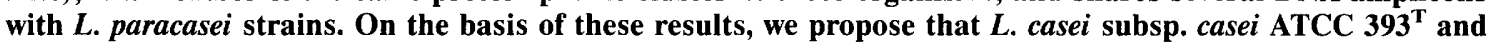
L. rhamnosus ATCC 15820 should be reclassified as members of Lactobacillus zeae nom. rev. (type strain, ATCC 15820), that strain ATCC 334 should be designated the neotype strain of $L$. case $i$ subsp. case $i$, and that the name $L$. paracasei should be rejected.
\end{abstract}

In a previous paper (4), we proposed that Lactobacillus casei subsp. casei ATCC 334 should be designated the neotype strain of Lactobacillus casei. However, our request for an opinion to this effect was rejected by the Judicial Commission of the International Committee on Systematic Bacteriology (15) on the basis of the fact that the requirements of Rules $18 \mathrm{e}$ and $18 \mathrm{~g}$ of the International Code of Nomenclature of Bacteria (10) had not been clearly and convincingly met. However, the true basis for the rejection was a misunderstanding of the wording, because the previously published facts do not support the opinion that "awarding an exception to the Rules" (15) is necessary. The facts are summarized below.

In 1966 the Subcommittee on Lactobacilli and Closely Related Organisms listed strain ATCC 393 (Streptobacterium casei No. 7 of Orla-Jensen) as the type strain of Lactobacillus casei Holland (7). There is, however, no evidence that strain ATCC $393^{\mathrm{T}}$ ( $\mathrm{T}=$ type strain) is one of the original strains described by Von Freudenreich (14). Hansen and Lessel (8) found some similarity between strain ATCC 393 and Bacillus sp. strain $\alpha$, one of Von Freudenreich's strains, and designated strain ATCC 393 the neotype strain of Lactobacillus casei. Subsequently, Mills and Lessel (11) studied the DNA-DNA relatedness of Lactobacillus casei and "Lactobacterium zeae" Kuznetsov 1959 and showed that the type strains of Lactobacillus casei (ATCC 393) and "Lactobacterium zeae" (ATCC 15820; later listed as a Lactobacillus casei subsp. rhamnosus strain in the American Type Culture Collection Catalogue of Strains [1]) are closely related (level of relatedness, $82 \%$ ).

\footnotetext{
* Corresponding author.

† Present address: Istituto Policattedra, Facoltà di Scienze, Universitá degli Studi di Verona, 37134 Verona, Italy.
}

These authors concluded that "Lactobacterium zeae" Kuznetsov 1959 is a subjective synonym of Lactobacillus casei.

However, this conclusion was not supported by the results of a more comprehensive DNA-DNA reassociation study (3), which included Lactobacillus casei ATCC $393^{\mathbf{T}}$, "Lactobacterium zeae" ATCC $15820^{\mathrm{T}}$, and representatives of all subspecies of Lactobacillus casei, including Lactobacillus casei subsp. casei, Lactobacillus casei subsp. alactosus, Lactobacillus casei subsp. rhamnosus, Lactobacillus casei subsp. tolerans, Lactobacillus casei subsp. pseudoplantarum, and Lactobacillus casei subsp. fusiformis. In their study Dellaglio et al. (3) obtained evidence that the level of DNA-DNA relatedness of strains ATCC $393^{\mathrm{T}}$ and ATCC $15820^{\mathrm{T}}$ is in fact more than $80 \%$, but that these strains are only moderately related (levels of relatedness 8 to $46 \%$ ) to all of the Lactobacillus casei subspecies (including Lactobacillus casei subsp. rhamnosus). On the other hand, high levels of DNA homology were found among and between Lactobacillus casei subsp. casei (the majority of strains), Lactobacillus casei subsp. alactosus Mills and Lessel 1973, and Lactobacillus casei subsp. pseudoplantarum Abo-Elnaga and Kandler 1965 strains, which is consistent with the genotype of Lactobacillus casei, and among Lactobacillus casei subsp. rhamnosus strains, indicating that these strains have a separate genotype (later designated Lactobacillus rhamnosus Collins, Phillips, and Zanoni 1989). Lactobacillus rhamnosus is only moderately related to strains ATCC $393^{\mathrm{T}}$ and ATCC $15820^{\mathrm{T}}$ and the Lactobacillus casei genotype. Thus, it is clear that "Lactobacterium zeae" is not a synonym of Lactobacillus casei and that the neotype strain of Lactobacillus casei subsp. casei (ATCC 393) is genotypically closely related to neither Lactobacillus casei nor the subspecies of Lactobacillus casei and therefore is not representative of the species. Another strain of Lactobacillus casei should be designated the neotype 
TABLE 1. Levels of genotypic relatedness among Lactobacillus zeae nom. rev., Lactobacillus casei, Lactobacillus paracasei, and Lactobacillus rhamnosus strains

\begin{tabular}{|c|c|c|c|}
\hline \multirow[b]{2}{*}{ Strain } & \multicolumn{2}{|c|}{$\begin{array}{l}\text { \% DNA homology with } \\
\text { DNA from }{ }^{a} \text { : }\end{array}$} & \multirow{2}{*}{$\begin{array}{l}\text { Original name on Approved Lists } \\
\text { of Bacterial Names }\end{array}$} \\
\hline & $\begin{array}{c}\text { Lactobacillus } \\
\text { casei } \\
\text { ATCC } 393^{\mathrm{T}}\end{array}$ & $\begin{array}{c}\text { Lactobacillus } \\
\text { casei } \\
\text { ATCC } 334^{\mathrm{T}}\end{array}$ & \\
\hline $\begin{array}{l}\text { Lactobacillus paracasei NCFB } 2713 \text { (= ATCC } 1983 \\
\quad=\text { ATCC } 27216=\text { DSM 20020) }\end{array}$ & 50 & 85 & Lactobacillus casei subsp. alactosus (former type strain) \\
\hline $\begin{array}{l}\text { Lactobacillus paracasei NCFB } 151^{\mathrm{T}}\left(=\text { ATCC } 25302^{\mathrm{T}}\right. \\
\left.\quad=\text { NCDO } 141^{\mathrm{T}}=\text { DSM } 5622^{\mathrm{T}}\right)^{c}\end{array}$ & 22 & 95 & Lactobacillus casei subsp. casei \\
\hline Lactobacillus paracasei DSM $20006^{c}$ & 35 & 79 & $\begin{array}{l}\text { Lactobacillus casei subsp. alactosus (formerly "Lactobacillus } \\
\text { casei subsp. fusiformis") }\end{array}$ \\
\hline Lactobacillus casei ATCC $334^{\mathrm{Tc}}$ & 43 & 100 & Lactobacillus casei subsp. casei \\
\hline $\begin{array}{l}\text { Lactobacillus paracasei NCFB } 2743 \text { (= ATCC } 25598 \\
\quad=\text { DSM 20008) }\end{array}$ & 33 & 86 & Lactobacillus casei subsp. pseudoplantarum (former type strain) \\
\hline Lactobacillus rhamnosus STPS I ${ }^{c}$ & $\mathrm{ND}^{d}$ & ND & \\
\hline Lactobacillus paracasei DSM $20207^{c}(=$ NCFB 1977) & 40 & 85 & Lactobacillus casei subsp. pseudoplantarum \\
\hline Lactobacillus sp. strain LHS ${ }^{c}$ & ND & ND & \\
\hline $\begin{array}{l}\text { Lactobacillus rhamnosus ATCC } 15820^{\mathrm{T}}\left(=\mathrm{DSM} 20178^{\mathrm{T}}\right. \\
\left.=\mathrm{NCIB} 9537^{\mathrm{T}}\right)\end{array}$ & 80 & 42 & "Lactobacterium zeae" (type strain) \\
\hline Lactobacillus paracasei ATCC 25180 & 47 & 83 & Lactobacillus casei subsp. alactosus \\
\hline $\begin{array}{l}\text { Lactobacillus casei ATCC } 393^{\mathrm{T}}\left(=\text { NCDO } 161^{\mathrm{T}}\right. \\
\left.=\text { DSM } 20011^{\mathrm{T}}\right)^{\mathrm{c}}\end{array}$ & 100 & 36 & Lactobacillus casei subsp. casei \\
\hline $\begin{array}{l}\text { Lactobacillus rhamnosus } \mathrm{NCFB} 243^{\mathrm{T}}\left(=\text { ATCC } 7469^{\mathrm{T}}\right. \\
\left.\quad=\text { DSM } 20021^{\mathrm{T}}=\mathrm{NCIB} 6375^{\mathrm{T}}\right)^{\mathrm{c}}\end{array}$ & 45 & 47 & Lactobacillus casei subsp. rhamnosus \\
\hline
\end{tabular}

a Data from references 3 and 4

${ }^{b}$ See reference 13 .

c Strain used in RAPD-PCR analyses.

${ }^{d} \mathrm{ND}$, not determined.

strain, as suggested by Dellaglio et al. (3). Surprisingly, these important facts have not been taken into account previously, as strain ATCC 393 was retained as the type strain of Lactobacillus casei (Orla-Jensen) Hansen and Lessel 1971 on the Approved Lists of Bacterial Names (13).
Further evidence which supports the conclusion that strain ATCC 393 is not a Lactobacillus casei strain was presented by Collins et al. (1a). However, the type strain of "Lactobacterium $z e a e "$ (ATCC 15820) was not included in the study of these authors, and the level of genetic relatedness between this spe-

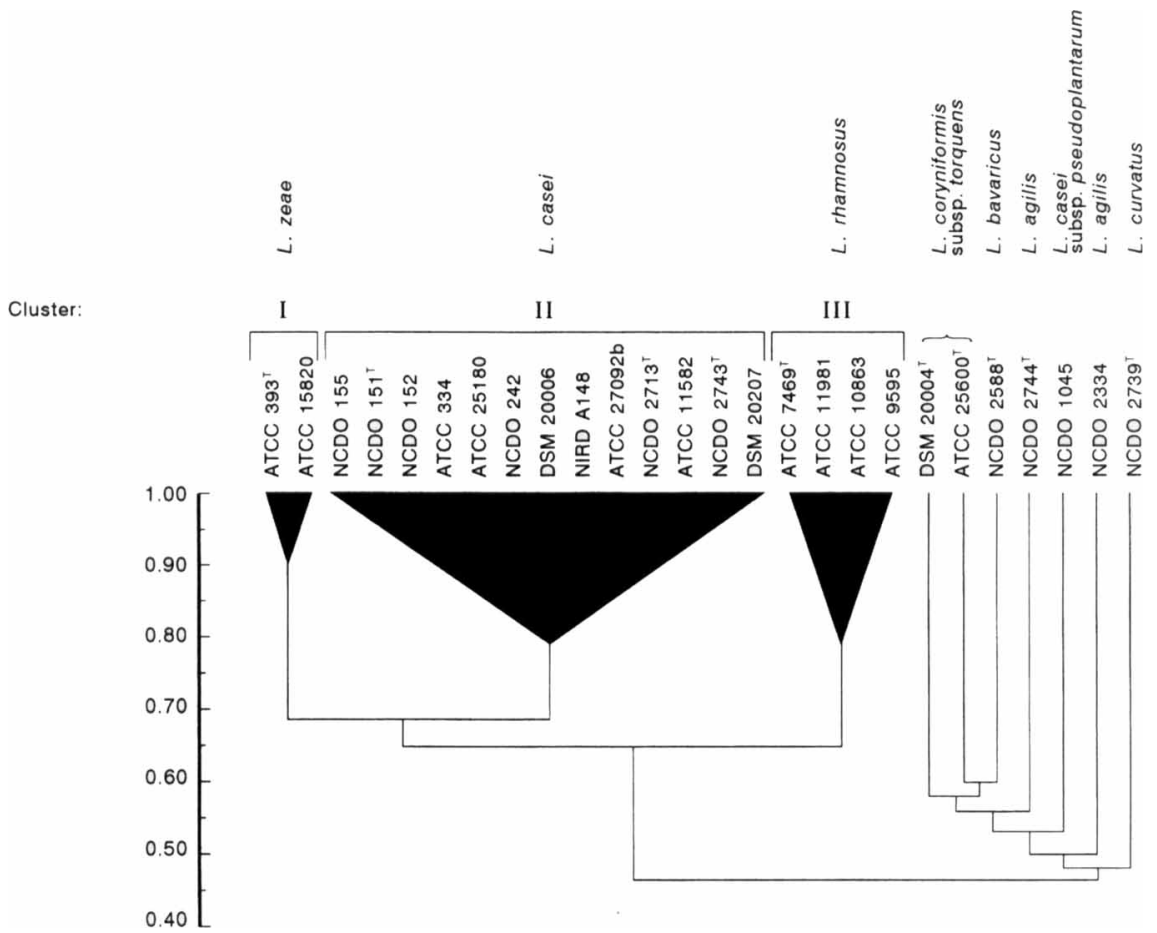

FIG. 1. Simplified dendrogram showing the clustering of Lactobacillus zeae nom. rev., Lactobacillus casei, and Lactobacillus rhamnosus obtained when we performed a numerical analysis of total soluble cell protein patterns. Based on the dendrogram published previously by Dellaglio et al. (4). 
cies and the type strain of Lactobacillus casei (ATCC 393) was not determined. Because of this, the true reason for the poor definition of the species Lactobacillus casei was not recognized. Collins et al. (1a) retained ATCC 393 as the type strain of Lactobacillus casei and reclassified Lactobacillus casei subsp. casei (which included the majority of the strains studied, including ATCC $334^{\mathrm{T}}$ ), Lactobacillus casei subsp. alactosus, Lactobacillus casei subsp. pseudoplantarum, and Lactobacillus casei subsp. tolerans strains as members of Lactobacillus paracasei.

In this paper we describe the DNA polymorphisms of representative strains having the different genotypes and present additional evidence that strain ATCC 393 should be excluded from the species Lactobacillus casei (12) Hansen and Lessel 1971. We also show that ATCC 334 is the most representative strain of Lactobacillus casei subsp. casei, Lactobacillus casei subsp. alactosus, and Lactobacillus casei subsp. pseudoplantarum and thus the most appropriate choice to be the neotype strain of Lactobacillus casei. These findings imply that the name Lactobacillus paracasei Collins, Phillips, and Zanoni 1989 should be rejected.

The strains included in this study are listed in Table 1. A simplified dendrogram based on the protein profile groups identified by Dellaglio et al. (4) is shown in Fig. 1. The randomly amplified polymorphic DNA PCR (RAPD-PCR) fingerprints of the type strains of Lactobacillus casei (ATCC 393), Lactobacillus paracasei (NCFB 151), and Lactobacillus rhamnosus (NCFB 243) and representative strains of subspecies included on the Approved Lists of Bacterial Names (13) are shown in Fig. 2. Strain STPS I was classified as a Lactobacillus rhamnosus strain (Table 1) on the basis of the results of physiological and biochemical tests (data not shown). Strain LHS was isolated from South African fortified wines. The RAPDPCR analyses were performed as described by Du Plessis and Dicks (5). Two single primers, primers OPL-01 (GGCATGA $\mathrm{CCT}$ ) and OPL-05 (ACGCAGGCAC) were used in this analysis.

Three genetic clusters were identified on the basis of RAPDPCR data (Fig. 2), confirming the results obtained in DNADNA hybridization experiments $(1 \mathrm{a}, 3)$ and a numerical analysis of total soluble cell protein patterns (4). The three clusters contained the type strains of Lactobacillus casei (ATCC 393), Lactobacillus paracasei (NCFB 151), and Lactobacillus rhamnosus (NCFB 243). The status of Lactobacillus rhamnosus as a separate species, as proposed by Collins et al. (1a) was clearly supported by our data.

The RAPD-PCR fingerprints of Lactobacillus casei subsp. casei ATCC $393^{\mathrm{T}}$ are different from the RAPD-PCR fingerprints obtained for other Lactobacillus casei subsp. casei strains (Fig. 2), indicating that strain ATCC $393^{\mathrm{T}}$ belongs to a separate genetic cluster. Lactobacillus casei subsp. casei ATCC $393^{\mathrm{T}}$ exhibited low DNA levels of homology (8 to $46 \%$ ) with other Lactobacillus casei subsp. casei strains, but a high level of DNA homology (80\%) with "Lactobacterium zeae" ATCC $15820^{\mathrm{T}}$ (3). Furthermore, Lactobacillus casei subsp. casei ATCC $393^{\mathrm{T}}$ and Lactobacillus rhamnosus ATCC $15820^{\mathrm{T}}$ belong to one protein profile cluster that is separate from the cluster containing other Lactobacillus spp. (Fig. 1). Thus, it is clear that strain ATCC $393^{\mathrm{T}}$, as described by Hansen and Lessel (8), is not a typical Lactobacillus casei strain but is a typical "Lactobacterium zeae" strain, as described by Kuznetsov (9). According to Rule $18 \mathrm{~g}$ of the International Code of Nomenclature of Bacteria, replacement of a neotype strain can be requested if the strain has become unsuitable. On the basis of DNA-DNA hybridization results, the results of a numerical analysis of total soluble cell protein profiles, and the results of RAPD-PCR analyses, we propose that Lactobacillus casei
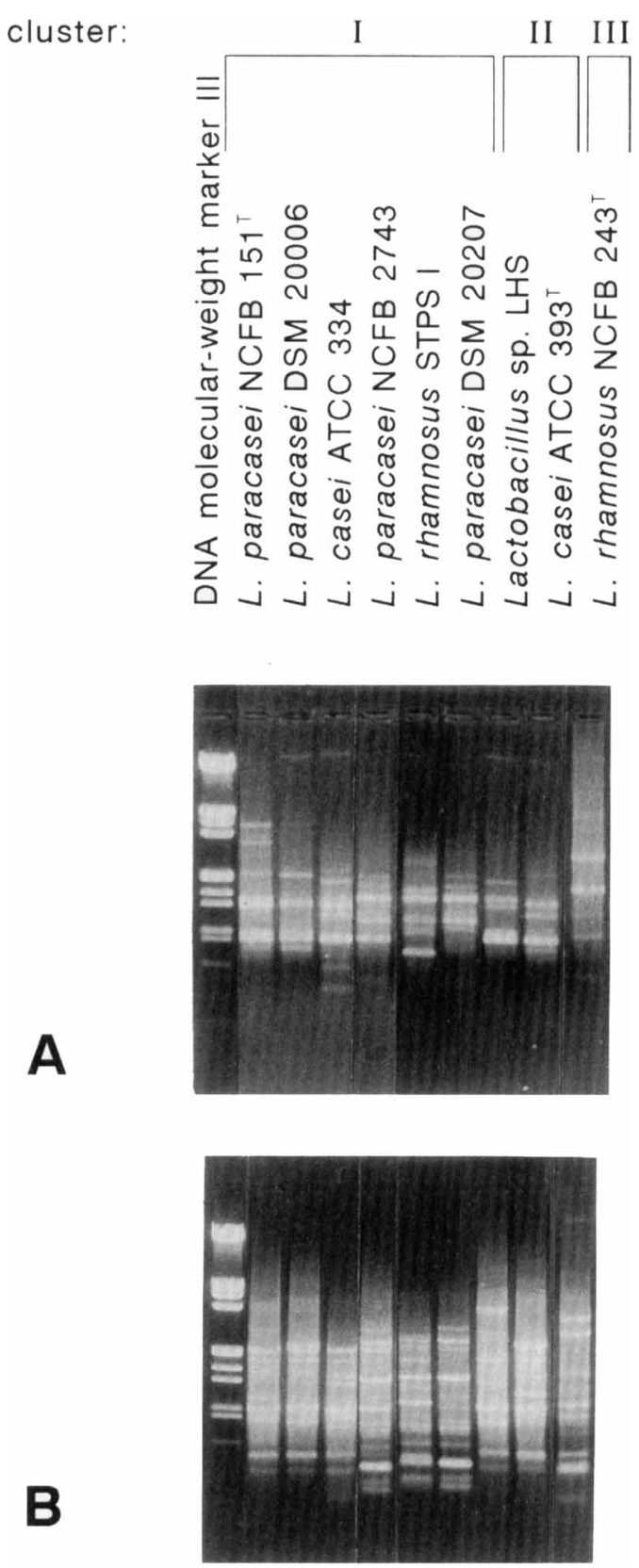

FIG. 2. Agarose gel electrophoresis of PCR amplification products. (A) Primer OPL-1. (B) Primer OPL-5.

subsp. casei ATCC $393^{\mathrm{T}}$ and Lactobacillus rhamnosus ATCC 15820 should be reclassified as Lactobacillus zeae (ex Kuznetsov 1959) nom. rev. strains (type strain, ATCC 15820). L-(+)Rhamnose is fermented by Lactobacillus zeae ATCC $15820^{\mathrm{T}}$, but not by strain ATCC $393^{\mathrm{T}}$, and thus this characteristic is not a distinctive trait of the species.

The overall RAPD-PCR profiles obtained for Lactobacillus casei subsp. casei ATCC $334^{\mathrm{T}}$, representative strains of the original genospecies Lactobacillus casei included in 1980 on the Approved Lists of Bacterial Names, and Lactobacillus paracasei Collins, Phillips, and Zanoni 1989 were similar (Fig. 2), indicating that these organisms belong to one genetic cluster. The majority of the typical strains of Lactobacillus casei previously placed in several subspecies, including Lactobacillus casei 
subsp. casei, Lactobacillus casei subsp. alactosus, Lactobacillus casei subsp. tolerans (not included in this study), and Lactobacillus casei subsp. pseudoplantarum, belong to the same genospecies as Lactobacillus casei ATCC $334^{\mathrm{T}}$. This important fact was ignored by Collins et al. (1a), who placed Lactobacillus casei subsp. casei (the majority of the strains studied), Lactobacillus casei subsp. alactosus, Lactobacillus casei subsp. tolerans, and Lactobacillus casei subsp. pseudoplantarum in the species Lactobacillus paracasei because the neotype strain of Lactobacillus casei subsp. casei (ATCC 393) belonged to a separate genospecies. Collins et al. (1a) did not consider the possibility that an appropriate type strain should be selected for the species Lactobacillus casei, as proposed by Dellaglio et al. (3). Our results clearly show that strain ATCC $334^{\mathrm{T}}$ is the most representative strain of the genospecies Lactobacillus casei and Lactobacillus paracasei. Furthermore, strain ATCC $334^{\mathrm{T}}$ has been included as a prominent and suitable reference strain in previous taxonomic studies $(2,3,6)$. According to Rule $18 \mathrm{e}$, the neotype strain of a species can be replaced by an original strain which was discovered subsequently. Rule 19 also applies; i.e., a reference strain which has no standing in nomenclature may be made a neotype strain. On the basis of these rules, we propose that strain ATCC 334 should be designated the neotype strain of Lactobacillus casei (Orla-Jensen 1916) Hansen and Lessel 1971 and that the name Lactobacillus paracasei Collins, Phillips, and Zanoni 1989 should be rejected.

Description of Lactobacillus zeae nom. rev. Surface colonies on MRS agar are smooth, glistening, white, and 1 to $2 \mathrm{~mm}$ in diameter. Cells are rod shaped (ca. 0.5 to 0.6 by 1.2 to $2.4 \mu \mathrm{m}$ ) and occur singly or in chains, depending on the growth conditions. Gram positive. Nonmotile. Spores are not formed. Grows at 10 and $45^{\circ} \mathrm{C}$. Facultatively heterofermentative. Produces mainly $\mathrm{L}-(+)$-lactic acid and a minor amount of $\mathrm{D}-(-)$ lactic acid. Acid is produced from amygdalin, cellobiose, fructose, galactose, gluconate, glucose, lactose, maltose, mannitol, mannose, melezitose, ribose, salicin, sucrose, tagatose, trehalose, and turanose. Acid is not produced from arabinose, dextrin, inositol, inulin, lactate, melibiose, raffinose, sorbitol (only strain ATCC $393^{\mathrm{T}}$ ), sorbose, starch, and xylose. Strain ATCC $15820^{\mathrm{T}}$ ferments rhamnose, whereas strain ATCC $393^{\mathrm{T}}$ does not. Gas is produced from gluconate. Catalase, benzidine, urease, and indole tests are negative. Nitrate is not reduced to nitrite, and ammonia is not produced from arginine. Esculin is hydrolyzed. The L-(+)-lactic acid dehydrogenase polyacrylamide gel electrophoretic pattern is identical to the pattern obtained for Lactobacillus casei and Lactobacillus rhamnosus. The murein type is Lys-D-Asp. The $\mathrm{G}+\mathrm{C}$ content of the DNA is 48 to 49 mol\%. The type strain is strain ATCC 15820. Isolated from corn steep liquor.

Description of Lactobacillus casei neotype strain ATCC 334. Neotype strain ATCC 334 of Lactobacillus casei has been described by Dellaglio et al. (4).

\section{REFERENCES}

1. American Type Culture Collection. 1989. Catalogue of strains. American Type Culture Collection, Rockville, Md.

1a.Collins, M. D., B. A. Phillips, and P. Zanoni. 1989. Deoxyribonucleic acid homology studies of Lactobacillus casei, Lactobacillus paracasei sp. nov. subsp. paracasei and subsp. tolerans, and Lactobacillus rhamnosus sp. nov. comb. nov. Int. J. Syst. Bacteriol. 39:105-108.

2. Dellaglio, F., S. Arrizza, and A. Ledda. 1981. Classification of citrate fermenting lactobacilli isolated from lamb stomach, sheep milk, and Pecerino Romano cheese. Zentralbl. Bakteriol. Parasitenkd. Infektionskr. Hyg. Abt. 1 Orig. Reihe C 2:349-356.

3. Dellaglio, F., V. Bottazzi, and M. Vescovo. 1975. Deoxyribonucleic acid homology among Lactobacillus species of the subgenus Streptobacterium Orla-Jensen. Int. J. Syst. Bacteriol. 25:160-172.

4. Dellaglio, F., L. M. T. Dicks, M. Du Toit, and S. Torriani. 1991. Designation of ATCC 334 in place of ATCC 393 (NCDO 161) as the neotype strain of Lactobacillus casei subsp. casei and rejection of the name Lactobacillus paracasei (Collins et al. 1989). Request for an opinion. Int. J. Syst. Bacteriol. 41:340-342.

5. Du Plessis, E. M., and L. M. T. Dicks. 1995. Evaluation of random amplified polymorphic DNA (RAPD)-PCR as a method to differentiate Lactobacillus acidophilus, Lactobacillus crispatus, Lactobacillus amylovorus, Lactobacillus gallinarum, Lactobacillus gasseri, and Lactobacillus johnsonii. Curr. Microbiol. 31:114-118.

6. Giorgi, A., S. Torriani, F. Dellaglio, G. Bo, E. Stola, and L. Bernuzzi. 1987. Identification of vaginal lactobacilli from asymptomic women. Microbiologica (Bologna) 10:377-384.

7. Hansen, P. A. 1968. Type strains of Lactobacillus species. American Type Culture Collection, Rockville, Md.

8. Hansen, P. A., and F. Lessel. 1971. Lactobacillus casei (Orla-Jensen) comb. nov. Int. J. Syst. Bacteriol. 21:69-71.

9. Kuznetsov, V. D. 1959. A new species of lactic acid bacteria. Mikrobiologiya 28:248-351

10. Lapage, S. P., P. H. A. Sneath, E. F. Lessel, V. B. D. Skerman, H. P. R Seeliger, and W. A. Clark (ed.) (editor for 1992 edition, P. H. A. Sneath). 1992. International code of nomenclature of bacteria. 1990 Revision. American Society for Microbiology, Washington, D. C.

11. Mills, C. K., and E. F. Lessel. 1973. Lactobacterium zeae Kuznetsov, a later subjective synonym of Lactobacillus casei (Orla-Jensen) Hansen and Lessel. Int. J. Syst. Bacteriol. 23:430-432.

12. Orla-Jensen, S. 1916. Maelkeri-Bakteriologi. Scønbergske Forlag, Copenhagen.

13. Skerman, V. B. D., V. McGowan, and P. H. A. Sneath (ed.). 1980. Approved lists of bacterial names. Int. J. Syst. Bacteriol. 30:225-420.

14. Von Freudenreich, E. 1889-1890. Recherches prèliminaires sur le role des bactéries dans la maturation du fromage de l'Emmenthal. Ann. Microgr. 2:257-283.

15. Wayne, L. G. 1994. Actions of the Judicial Commission of the International Committee on Systematic Bacteriology on requests for opinions published between January 1985 and July 1993. Int. J. Syst. Bacteriol. 44:177-178. 